\title{
The Ethical Legacy of Hippocrates
}

\author{
Goran Stojanović
}

\begin{abstract}
The text analyses the ethical content of the Hippocratic Oath, evaluates its significance for modern-day medicine and answers the question of how relevant it is for today's physicians. The history of the Oath is explored from its origin to modern-day adaptations. The paper explains the difference of expressing moral norms through an oath, a promise and a code. The ethical contents of Hippocratic ethics are divided into three segments: the covenant, the code and decorum. The paper further discusses the interpretation of controversial parts on abortion, euthanasia and the use of surgery. In his other works, Hippocrates emphasises high morality and requires physicians to be virtuous, exemplary humanists and to preserve the honour of their profession. In spite of all its faults, the Hippocratic Oath continues to set an example for the medical practice by emphasising the responsibility of the physician for the well-being of the patient. It is necessary that physicians possess not only technical knowledge, but also ethical education, enabling them to make conscientious moral decisions. The Oath is old, non-authentic, modified, differently interpreted and incomplete, but remains relevant for modern-day biomedical ethics.
\end{abstract}

Key words: Hippocrates; Oath; Professional ethics; Ancient medicine.
(1) Department of Philosophy, Faculty of Philosophy, University of Banja Luka, the Republic of Srpska, Bosnia and Herzegovina.

Correspondence: GORAN STOJANOVIĆ

E: goran.stojanovic@ff.unibl.org

\section{Introduction: The legend of Hippocrates}

Hippocrates (460-377 BCE) lived in the golden age of classical antiquity. It is the period of the rule of Pericles (495-429), the rise and fall of Athens in the Peloponnesian war (431-404), the construction of the Pantheon (447-433), emergence of Thucydides' critical historiography (454-396). The tragedies of Sophocles (497-406) and Euripides (480-406) gain popularity, as well as the comedies of Aristophanes (446-386). It is a time when philosophy shifts its focus of research from cosmology towards issues of anthropology. Sophists appear, as paid travel teachers. Socrates (470399 BCE) and his maieutic method of revealing the truth gave birth to ethics as a philosophical discipline. It is surprising that, in spite of knowing a fair amount about this period, a lot of infor- mation on the life of the most popular physician of the world is not known. Most of what is known survived as idealised legends. ${ }^{1}$

Reliable contemporary historical sources mentioning Hippocrates are quite scarce. Plato said he was one of the most renowned physicians of classical antiquity in his dialogues Phaedrus ${ }^{2}$ and Protagoras. ${ }^{3}$ The other source is Aristotle's statement that Hippocrates' popularity is not due to his physical stature (Figure 1), noble background, nor economic power, but primarily his knowledge of ailments. ${ }^{4}$

Legend has it that Hippocrates is descendent directly from Asclepius, the god of medicine. He 


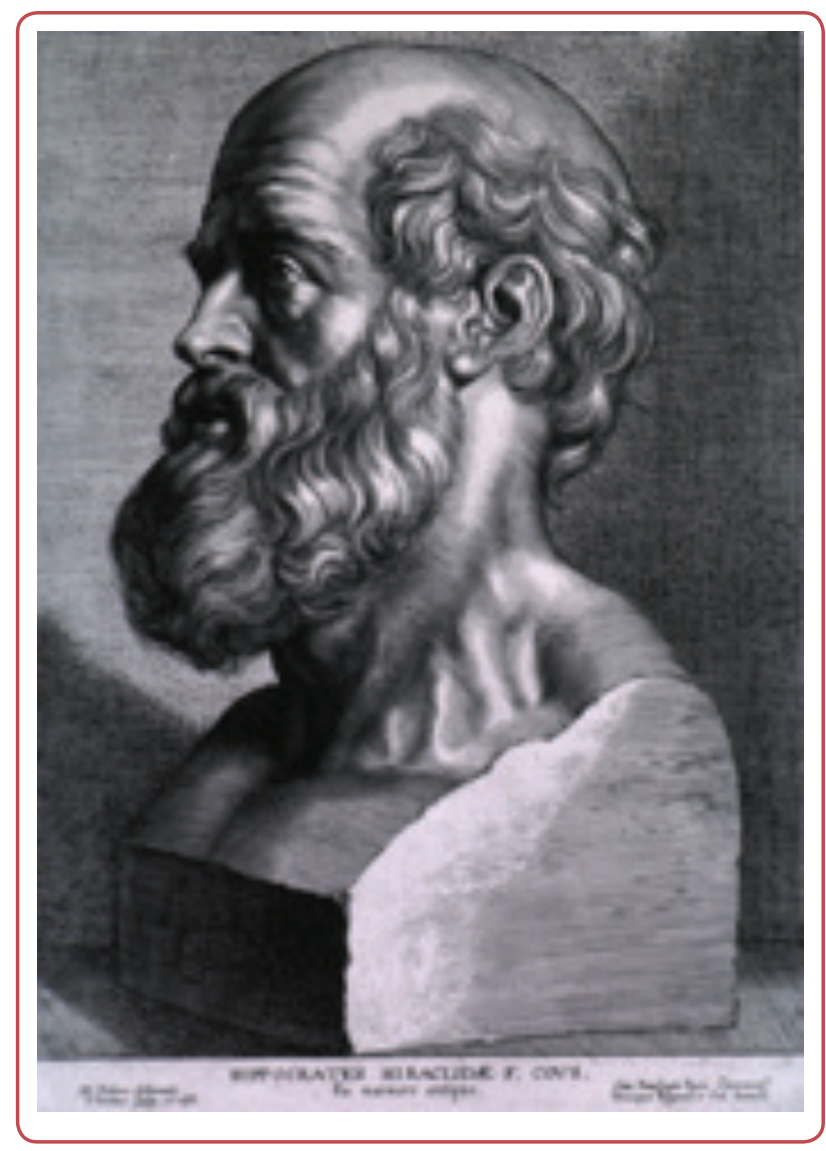

Figure 1: Portrait of Hippocrates engraved by P. Pontius after Peter Paul Rubens (1638).

was first taught by his father Heraclides, the chief priest of the Asclepeion temples on the island of Kos. His further education was deepened by the most renowned teachers of classical antiquity; Gorgias from Leontin taught him rhetoric and Democritus from Abdera taught him philosophy. He had discussions with Socrates' teacher Anaxagoras, who brought philosophy to Athens. This quickly led him to discard the traditional supernatural image of the world and medicine and embrace the philosophical approach to seeking truth by revealing the causes of phenomena. Hippocrates thus became the first person who scientifically studied and categorised diseases into acute, chronic, endemic and epidemic. His approach to case studies was very methodical: diagnose the disease, describe its symptoms, predict its consequences and prescribe therapy. He kept detailed case-histories, kept note of both his failures and successes, which enabled him to be very precise in predicting the outcome of a disease for a patient. He held a holistic approach to treatment and asked the patient to completely change their lifestyle, introducing appropriate physical activity and a balanced diet. Unlike other physicians

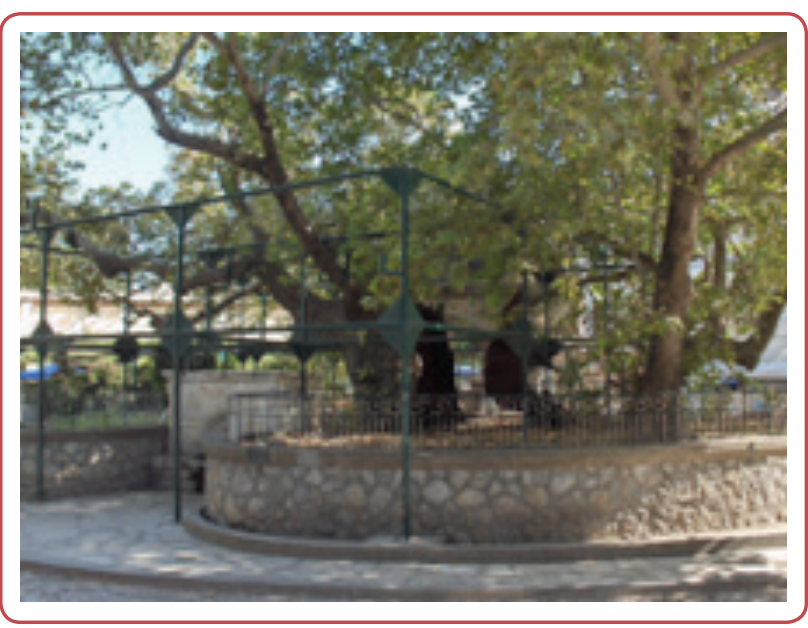

Figure 2: The "Tree of Hippocrates" on the island of Kos. The place where Hippocrates treated patients and lectured students..

of the time, he required that his students lead a moral life.

Travelling from one polis to another, Hippocrates practised his medicine in public squares (Figure 2). The new art of healing quickly spread through the Mediterranean peninsula thanks to its positive results. As the approach was gaining popularity, the number of Hippocrates' essays grew and led to a collection of sixty books published in c. 280 BCE in the library of Alexandria, entitled Corpus Hippocraticum. This collection was most likely written over an extended period of time (420350 BCE) by dozens of Hippocrates' students. The books are in no particular order, and contain contradictory philosophical essays, research notes, case studies and public lectures. The topics and writing styles are various and address both beginners and advanced physicians. Aside from the differences among the texts, there are clear similarities as well. When it comes to style, there is a visible influence of the Gorgias rhetoric with the use of antithesis, assonance, anaphora, long prologues and epilogues, the use of concise aphorisms. In terms of the topic, when diagnosing diseases and determining the therapy, all authors of the Corpus Hippocraticum express naturalistic determinism and reject mythical explanations of diseases.

\section{Origin of the Oath}

Of all the texts in Corpus Hippocraticum, the most relevant for medical ethics is also the most mys- 
terious one, the Oath ('Оокоร; Ius Iurandum). ${ }^{5}$ It is not known what its significance was and whether Hippocrates even used it, whether it referred only to his students or to all physicians and whether it is the only text of its kind. But what is known is that the Oath did not reflect the moral values of the society of classical antiquity. It is also surprising that it is not even mentioned in the rest of the Corpus and that it contradicts views expressed in other texts by Hippocrates. Consequently, there are few medical ethics historians who believe that it was originally written by Hippocrates. ${ }^{6}$ In this paper it is subscribed to the convincing argumentation of Ludwig Edelstein that the Oath is Pythagoras' manifesto and not authentic teaching of Hippocrates. ${ }^{7}$ Only in Pythagoras' philosophy ascetic ethics is found which underlines the sanctity of the soul and moral virtue. Pythagoras thus requires treatment by way of diets and exercise, professing to the gods that the students would live in a brotherly community, respect the teacher like a father and keep their knowledge a secret because it is too dangerous to be disseminated among the masses. On the other hand, he bans abortion and euthanasia, bloodletting and the use of surgery. Pythagoras instructs that the soul should be kept morally pure by clearly defining what should be done and what should be forbidden.

Contrary to the popular belief, not only is the Oath not authentic, but the most famous phrase in medicine, primum non nocere (first do no harm), is not originally by Hippocrates either. ${ }^{8}$ The ubiquitousness of this principle can be demonstrated by a quick search of the PubMed database, which returned 634 occurrences in titles of scientific papers published between 1955 and 2020. The Latin phrase was first used by mythologist and physician Thomas Inman. ${ }^{9}$ But it is true that Hippocrates mentioned this principle in his book Epidemics 1, saying: "As to diseases, make a habit of two things - to help or at least do no harm. The Art has three factors, the disease, the patient, the physician. The physician is the servant of the Art. The patient must cooperate with the physician in combating the disease."10

As far as the Oath itself is concerned, its history is assumed to start around 400 BCE. The earliest existing fragment dates from 275 CE (Figure 3). The first historical source which mentions it, commenting on the prohibition of abortion, comes from the physician of the Roman emper-

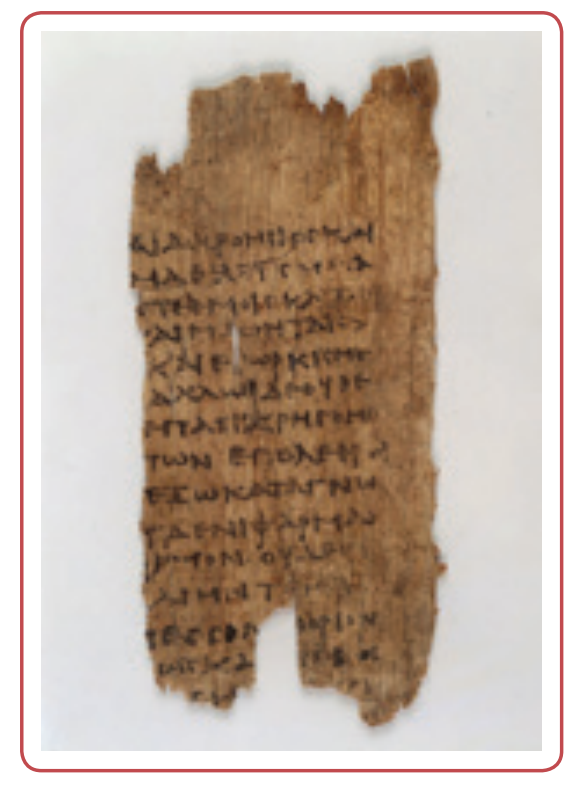

Figure 3: The oldest fragment of the Oath (c. 275 CE); Papyrus Oxyrhynchus 2547.

or Claudius Scribonius Largus (c. 1-50). Religious thinkers of the Middle Ages adapted the text of the Oath to their own world views, just like they did with the philosophy of Plato and Aristotle (Figure 4). The original text of the Oath in Old Greek was lost for a while, and then re-surfaced in

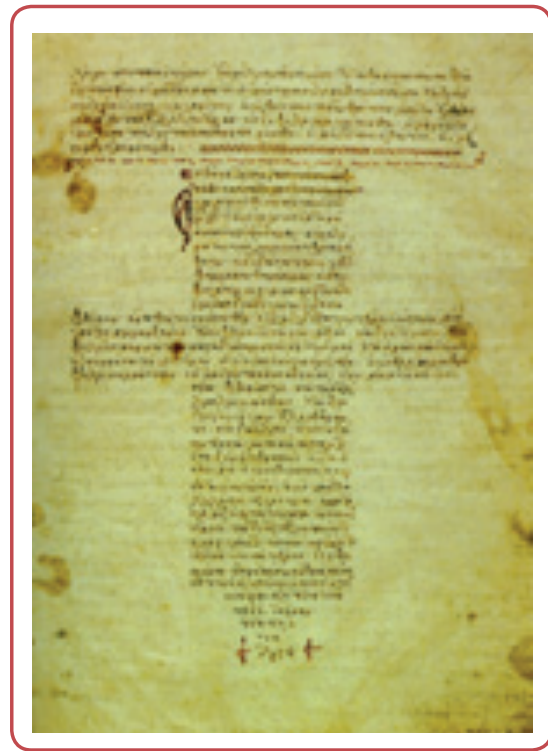

Figure 4: The Oath written in the shape of a cross (12th century); Vatican Manuscript Urbinus 64. folio 116.

1508 (Figure 5). The first translation of this original version was into French and was used at the Montpellier medical school graduation ceremony in 1804. It was translated into other languages of the world as well, but its use did not become widespread in medical education and practice. ${ }^{11}$ The situation took a drastic turn after the 1946 Nuremberg trials in which Nazi physicians were indicted and charged for medical crimes committed in World War II. Consequently, the number of medical schools using some version of the Oath increased from $29 \%$ in 1928 to $98 \%$ in $1993 .{ }^{12}$ 


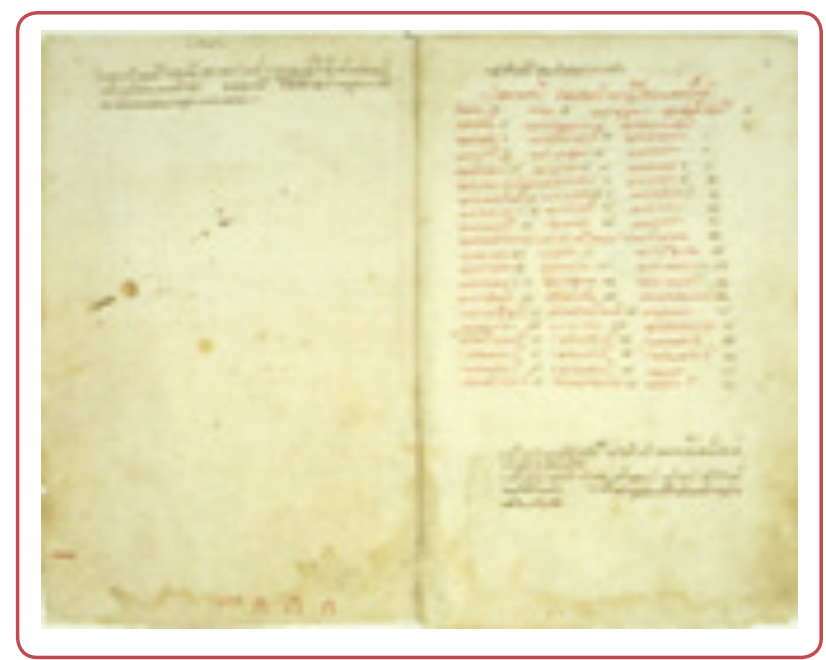

Figure 5: The content of the first translation of Hippocrates' works into Latin, translated by Marcus Fabius Calvus (1526).

The original Hippocratic Oath endures in only $2 \%$ of medical schools, while most others adopted a significantly revised version. Further, all modern-day modified versions of the Oath abandoned the prohibition of surgery and tuitions; $50 \%$ mention punishment for violating the oath, $8 \%$ invoke higher powers, $14 \%$ prohibit euthanasia, $8 \%$ prohibit abortion and $3 \%$ prohibit sexual intercourse with a patient. ${ }^{13}$ Today, many schools use a contemporary successor of the Hippocratic Oath in the form of the World Medical Association (WMA) Declaration of Geneva (1948) or the 1964 rewrite by Louis Lasagna, the then Dean of the Tufts University School of Medicine. Some medical schools asked their students to draft their own oaths which they would later officially take. ${ }^{14}$

\section{The Physician's Oath}

Before the contents of the Oath is analysed in this paper, the difference between an oath and a promise should be clarified. An oath carries more moral weight because it is not an everyday declaration of intent like a promise is. ${ }^{15} \mathrm{An}$ oath is formal and solemn, taken exclusively in public before an entire community, the most sacred of the members of a tripartite relationship (I-Sacred-You). It is impersonal and applies to all persons in general. It is not context-dependent, nor limited in duration, it is binding for life. A violation of the Oath is highly detrimental to the honour and reputation of the offender, because it defines not only what one is supposed to do, but what kind of a person one should be. This is why oaths are taken by other occupations significant for the social community, such as presidents, judges, soldiers and teachers. On the other hand, a promise is an assurance given to another about the intention of our moral action, by carrying out or restraining from future action. It is made informally and privately in a bipartite relationship (I-You). It is always personal, limited in duration and context-dependent. A change of circumstances can void the promise. For this reason, judgement may be passed for violation of a promise, but it will not jeopardise the offender's integrity. Further, a promise and an oath must be distinguished from an ethical code. A code is a collection of systematised moral rules that distinguish desirable from undesirable behaviour. A code explicitly and clearly lists what should or should not be done. It does not invoke honour or solemn oath-taking before a sacred entity. It is subject to frequent amendments and modifications. An oath, a promise and a code are different ways of expressing moral norms - the purposeful and free acceptance of ethical standards in one's behaviour. Through socialisation their adoption creates a uniform system of values which makes a human community possible. Their adoption in a professional context instigate an environment of reliability, loyalty, benevolence and solidarity.

In terms of contents, the Oath can be divided into two segments. ${ }^{16}$ The first segment is the covenant to preserve medical knowledge through regulating the relation between the teacher and the students. The second part is the code, comprising imperative norms towards treating diseases (abortion, euthanasia, surgery) and correct bedside manner (sexual chastity and physician-patient privilege). The covenant begins by invoking the gods as witnesses. The gods metaphorically determine the course of treatment as a team endeavour. Apollo is first called upon, as the god of healing, poetry and music (emphasizing the significance of subtle feeling and empathy), truth and reason (exploring the natural causes of the disease), prophecy (importance of prognostics for the course of treatment), love for other people (empathy for the diseased). In assuming divine powers from his father, Apollo, Asclepius fully devotes himself to medicine and each of his daughters becomes a symbol for one of the branches of medicine: Hygieia for epidemiology and public health, Panacea for pharmacology, Iaso for nursing, Aegle for nutritionism, and his son Telesphoros for rehabilitation medicine. It is impossible 
to know for certain what Hippocrates' religious views were. The strict naturalistic approach in his other papers contradicts addressing so many gods in the preamble of the Oath. It seems most plausible that this kind of introduction was taken from earlier Homeric oaths as part of expressing traditionally accepted morals to further strengthen the foundation and upholding of the oath. The oath asks the physician to be at the same time the creator of new knowledge as a student and the guardian of acquired knowledge as a teacher of new generations. The oath also asks for solidarity. Any acquired know-ledge which benefits patients should not be jealously guarded, but rather distributed with one's colleagues. Colleagues should be respected and assisted like brothers. In insisting on education and moral instruction for new generations, Hippocrates is similar to Socrates.

\section{The Physician's Code}

The Oath contradicts itself when it comes to abortion. Abortion and infanticide were accepted and practised in ancient Greece. According to social consensus, motherhood and the establishment of a family were desirable. However, at the same time, abortion or abandonment of born children was not deemed immoral. Motives for abortion were different - danger to the mother's life, children with deformities, economic status, desire for male offspring, hiding adultery, preservation of youthful good looks, loss of freedom through childcare. Several methods of abortion were used at the time, the most popular of which was mechanical perforation of the placenta. Others include vaginal suppositories made of cedar oil and wool. Hippocrates also suggested repeated high jumps. ${ }^{17}$ Embryotomy existed as a procedure as well, but only as a last resort, when the foetus was already dead and the mother's life endangered. Children from unwanted pregnancies were left outside temples to be sold into slavery or taken in by childless couples. Less caring parents carried out infanticide most commonly by drowning. The man had the right to make medical decisions on the woman's behalf, since he, as the provider of the semen which the woman only nurtures, was considered the only true owner of the foetus. The traditional Greek physician was not opposed to the patriarchy in the society, nor to abortion. Representatives of the pro-life movement are therefore wrong in claiming that medicine was against abortion from the very beginning of the practice. It is most likely that the Oath only prohibits one of the abortion methods - the use of destructive medicaments that would be harmful for the mother. The first mention of the foetus as a person and abortion as murder comes half a millennium after the Oath was drafted, from the Roman physician Scribonius Largus. He believed abortion should be prohibited because it violates the fundamental goal of medicine - the protection of health and preservation of life. His interpretation of the prohibition of abortion was adopted by all subsequent translations of the Oath.

The Oath is also in contradiction when it comes to euthanasia. Hippocrates is against it in the Oath, but allows it elsewhere, saying that the task of the art of healing, apart from relieving patients from pain, is to refuse treating incurable diseases. ${ }^{17}$ It should be noted that the ancient Greeks had a specific understanding of death. Death is completely natural and an expression of human essence. Gods differ from man precisely in their immortality. By nature, man is constrained by fate and death. The most exalted thing a person can do in life is to fulfil their destiny/purpose and to have a good death. This understanding of human life gave Greeks two interpretations of death. The first is the desirable death of a hero, when a sacrifice is made in order to fulfil the destiny or when one's honour should be restored, tarnished by previous wrongdoings.

The second is the undesirable and ignominious death of a coward; one escapes life because of poverty, lack of purpose in life or desire to join a loved one in the afterlife. In such an understanding of death, euthanasia did not have a negative connotation. On the contrary, it signified a good death, a desirable death with as little pain as possible. It is only later that it developed the medical connotation of assisted suicide. Like abortion, euthanasia was common practice in the Greek society. Euthanasia with consent was allowed as an act of mercy, while euthanasia without consent was condemned as murder.

Discussing the value of life, philosophers of classical antiquity offered various answers to the question of the morality of abortion and euthanasia. A group of philosophers who advocated ascetic morality and viewed life as sacred, forbidding its early termination either by abortion or euthanasia, were the Pythagoreans. According to Pythag- 
oras, the soul which enters the body at conception represents the greatest value. The body is material, its destiny is to decay and die; the soul is of divine origin and its destiny is to be purified by virtue of a moral life and to ascend to its spiritual source. A person who leads a morally wrong life demeans their soul, which is therefore forced to return, after death, to the material world in some other physical shape. It is for this reason that Pythagoras forbids abortion, euthanasia, suicide and eating meat, because these deeds are immoral and void the value of the soul.

Plato agreed that the soul holds great value, but unlike Pythagoras, he believed that its entry into the body does not happen at conception, but rather at birth, when the baby draws its first breath. In order to create the perfect state, aside from abortion, Plato suggests eugenics as well, imposing a law which would forbid persons who are not in their peak years (25-55 for men and 2040 for women) to procreate. Such children would be born physically and mentally underdeveloped, which would pose a substantial burden on the entire community. Plato allows withdrawal from treatment (passive euthanasia) in case of a terminal illness followed by great pain but forbids administering lethal poison (active euthanasia).

His famous student, Aristotle, also expresses the importance of planned reproduction, because overcrowding soon breeds poverty and immorality. Unlike his teacher, Aristotle does not view the soul in religious terms. The soul is a vital principle of life and is inseparable from the body. The soul cannot transcend death. It vanishes as the body does, just as sight vanishes as the eye does. The only way for a person to transcend death is through noble deeds and through offspring. Everything that is alive possesses one of the three forms of the soul: a vegetative soul which belongs to the plant life, a sensitive soul which animals possess, while humans are the only creatures which possess a rational soul. Aristotle's view is that abortion is morally permissible before the animalistic soul comes about (40 days after conception for male children and 90 days for female children). Aristotle forbids euthanasia as an expression of weak character and submission to the disease. A virtuous man dies bravely, not like a coward with a defeated spirit.

In the most significant philosophy of the Graeco-Roman times after Aristotle, Seneca, a Stoic philosopher, also believed that the soul is received at first breath. Up until then the foetus was part of the mother, just as a piece of fruit was part of the tree, so abortion is completely justified, while infanticide was forbidden. Seneca allowed euthanasia, believing that man is a rational being, fully entitled to heroically take his own life in defiance of a predetermined destiny. Epicurus would add that death is not something to fear, because for as long as we exist, there is no death and when death comes, we are no more.

The segment on prohibiting surgery also invoked differing interpretations, so it was assumed that surgery was not entirely banned, but rather that it was a prohibition of the removal of gallstones, ${ }^{19}$ kidney stone ${ }^{20}$ and testicles, ${ }^{21}$ a Pythagorean disapproval the disfigurement of the human body, ${ }^{22}$ or that surgery was indeed banned, but that the segment was added much later to differentiate between the specialisation of physician and surgeons. ${ }^{23}$ Whichever interpretation one accepts, it is clear that Hippocrates believes that high-risk life-threatening surgery is a serious medical mistake. Mistakes continue to be a serious issue in modern-day medicine, often covered up for fear of financial lawsuits, bad publicity, loss of good reputation and the patients' trust. ${ }^{24}$ Later on in the Oath, Hippocrates emphasises the importance of safeguarding the patient's trust. Confidentiality between the physician and the patient was extremely important in classical antiquity, when modern laboratory diagnostics were not available. A patient shares numerous confidential information with their physician (sexual orientation, abuse of narcotics, use of birth control, abortion, psychiatric care) with the intention of keeping it secret, and not a source of gossip. Abuse and disclosure of this information is immoral because it violates the patient's privacy and confidence in the physician, without which the patient could withhold information which is crucial for their treatment. Hippocrates condemns sexual exploitation as a particular violation of trust, because it significantly damages the integrity of medicine and the well-being of the patient.

\section{The Physician's Decorum}

Aside from the Oath, Hippocrates devoted four more texts to morality and decorum of physicians. The text entitled The Law comprises notes from a public speech given at a time when there was no state-organised medical practice, which was full of charlatans looking for quick money. Under the 
influence of stoic philosophy, it demands that prior to taking on medical practise, physicians first must obtain proper education and that one who is not naturally predisposed to be a physician is rejected from the profession. "The learning of medicine may be likened to the growth of plants. Our natural ability is the soil. The views of our teachers are as it were the seeds. Learning from childhood is analogous to the seeds falling betimes upon the prepared ground." 25 The text Physician teaches us about the good manners which any medical practitioner should nurture. In order to gain the respect of the people and to attract patients, a physician must epitomise health, should wear decent clothes, should be clean and have a pleasant scent. They must be controlled, calm and kind, just, close to the patient, serious, but not strict. ${ }^{26}$ The book Decorum was not meant to be published. It is a set of fragmented notes for public lectures on proper behaviour towards the patient. ${ }^{27}$ It requires physicians to possess the virtues of a stoic sage: wisdom (to know the difference between good and bad), courage (to know what to fear and what not), self-control (to know which urges to support, which to moderate, and which to ignore). It requires physicians to make gracious speeches, build a good reputation, be merciful to those who are ill and do not have money to pay for treatment, anticipate problems, respond to questions and objections, examine patients carefully, visit and encourage the patient frequently, task his students with overseeing the administration of therapy. The book Precepts was written in a vague aphoristic style with a noticeable influence of Epicurean philosophy. The first part of the text points out that medicine must be based on the observation of the facts and verification of hypotheses. The second part of the text expresses humanism: "For where there is love of man, there is also love of the art." ${ }^{28}$ It is advised that the treatment is charged only after successful completion and that the poor are treated completely free of charge; that expensive gifts should be refused, because they damage one's reputation; but also that it is unbecoming to honour a patient's gratitude by accepting symbolic gifts. Fellow physicians are referred to as "brothers in art" and forbids any kind of jealousy as a sign of an unrefined character. It offers several other pieces of advice on how to keep a successful practice and achieve high reputation, give public lectures, treat charlatan healers and cope with the patients' whimsy.

\section{The Currency of the Hippocratic Oath}

A few objections can be made to the Hippocratic Oath. As it is presented, most of the Oath does not address treatment. The parts on abortion and euthanasia are not so direct and are therefore subject to various interpretations. The responsibility of the physician towards the community is not defined. Slavery as a social system is accepted. There is no clearly defined punishment for violation of the oath. On that note, Plato added to it the suggestion that a physician who deliberately administers poison to a patient should be put to his death by the same means and if his negligence causes a patient's death, he should be put to public trial. ${ }^{29}$ It lacks the cooperative model of the physician-patient relationship. ${ }^{30}$ The physician makes paternalistic decisions on everything and the patient's only task is to obey. ${ }^{31}$ Other objections are that it is pagan, contrary to the values of the Judeo-Christian West; ${ }^{32}$ that it is out of date because it is based on obsolete medicine and is not suitable for the modern-day research-based pharmacology and modern technologies; ${ }^{33}$ or that it is incomplete and fails to express all the values of medical ethics: non-maleficence (primum non nocere), beneficence (act in the interest of the patient), confidentiality (secrecy in the physician-patient relationship), dignity (the patient is entitled to being treated with respect), autonomy (the patient's right to refuse or chose the course of treatment), fairness (equal distribution of benefits and risks). It can be said that the Oath explicitly states the first value and implicitly the second one. It would agree with the third and fourth, while it would not recognise the fifth and sixth value. ${ }^{34}$

It is because of these objections that one can rightly ask how relevant the Hippocratic Oath is for modern-day man. Contemporary society has witnessed vast scientific and technological advancements and significant economic and geopolitical changes. Today's students who put on their white robes for the first time, face technologies which were unknown to Hippocrates. One can only imagine what Hippocrates would think if he were to attend complex remote-controlled surgery using robotics, heart transplants, the use of radiology and ultrasound in diagnostics, mechanical respirators and artificial organs. He would certainly have been amazed with the progress, but it is hard to imagine 
he would be happy that his medicine has become a profitable industry, that it forgot about the patients and turned them into anonymous numbers, turned treatment into a list of administrative procedures and medicine into a business model.

\section{Acknowledgements}

None.

\section{Conflict of interest}

\section{Conclusion}

Regardless of all its faults, the Oath was in fact well designed, which is why it still serves as a role model when drafting ethical codes for various professions. It is a special warning to professional codes that primarily protect their practitioners and employers from paying for expensive lawsuits and do not serve the well-being of their clients. The Oath has rightly remained a source of inspiration because it has the ability to develop moral sensibility and has a positive impact on the conscience of future health workers. A promise made in public continues to result in ousting, or at least condemning charlatans, frauds and immorality in medicine. Moral education teaches medical staff to think more clearly, to create valid arguments, to set an example to younger colleagues with their own behaviour, to show discipline in their work on forming new habits and improving their knowledge. When young physicians utter the words of the oath, they do so by reflecting on their moral values and the values of the culture they live in, breeding a sense of community and demonstrating maturity of character to the patient, who seeks confidence and security. At a time of hastened biotechnological progress, the human relationship between physician and patient is more important than ever. In its essence, the Hippocratic Oath expresses humanism, and is therefore still current. It is not a relic of the past, nor just another idea in a graveyard of surpassed theories. One can clearly see that the issues of medical ethics which Hippocrates contemplated have remained just as important despite the challenges of modern times. Eras, cultures, diseases and treatments may change, but care for the diseased has and always will be the primary ethical norm of medicine. Thus, it can be concluded that: the Oath is old, non-authentic, modified, differently interpreted and incomplete, but remains relevant - a beacon of immeasurable importance to medical ethics.
None.

\section{References}

1. Pinault JR. Hippocratic lives and legends: studies in ancient medicine. Vol. 4. Leiden: Brill; 1997.

2. Platon. Platonova djela: Ijon, Gozba, Fedar, Odbrana Sokratova Kriton. [Platonian works: Ion, Symposium, Phaedrus, Apology of Socrates, Crito]. Beograd: Dereta; 2006. p. 270bd. Serbian.

3. Platon. Protagora/Sofist. [Protagoras/Sophist] Zagreb: Naprijed; 1975. p. 311b-c. Croatian.

4. Aristotel. Politika. [Politic] Zagreb: Globus; 1988. p. 1326a.15. Croatian.

5. Hippocrates. Oath. In: Page TE, editor. Hippocrates Vol. I. Cambridge: Harvard University Press. 1957. p. 299-301.

6. Nittis $S$. The Authorship and probable date of the Hippocratic Oath. Bull Hist Med 1940;8(7):1012-21.

7. Edelstein L. The Hippocratic Oath: text, translation and interpretation. In: Temkin O, Temkin L, editors. Ancient Medicine. Baltimore: The Johns Hopkins University Press; 1967. p. 3-65.

8. Smith CM. Origin and uses of primum non nocere-above all, do no harm! J Clin Pharmacol 2005;45(4):371-7.

9. Inman T. Foundation for a new theory and practice of medicine. London: John Churchill; 1860. p. 244.

10. Hippocrates. Epidemics 1. In: Page TE, editor. Hippocrates Vol. I. Cambridge: Harvard University Press; 1957. p. 149.

11. Rütten T. François Tissard and his 1508 edition of the Hippocratic Oath. In: Derejik PJ. Hippocrates in context: Papers read at the XIth International Hippocrates Colloquium. University of Newcastle upon Tyne 27-31 Aug 2002. Leiden: Brill Academic Publishers; 2005. p. 465-491.

12. Orr RD. The Hippocratic Oath: is it still relevant? [Internet]. Loma Linda University Center for Christian Bioethics Update 1998;14(1) [cited 2020 Sep 4]. Available from: https:// bit.ly/2ZeoxXz.

13. Orr RD, Pang N, Pellegrino ED, Siegler M. Use of the Hippocratic Oath: a review of twentieth-century practice and a content analysis of oaths administered in medical schools in the U.S. and Canada in 1993. J Clin Ethics 1997;8:377-88.

14. Gruenbaum SE, Jotkowitz AB. Content analysis of ethical codes written by medical students compared with other codes of medical ethics. Eur J Intern Med 2009;20:101-4.

15. Sulmasy DP. What is an oath and why should a physician swear one? Theor Med Bioeth 1999;20:329-46.

16. Carrick P. Medical ethics in ancient world. Washington, DC: Georgetown University Press; 2001. p. 84.

17. Hippocrates. On the nature of the child. In: Potter P, editor. Hippocrates Vol. X. Cambridge: Harvard University Press; 2012. p. 25-95.

18. Hippocrates. The Art. In: Page TE, editor. Hippocrates Vol. II. Cambridge: Harvard University Press; 1957; p. 203.

19. Veatch RM. A theory of medical ethics. New York: Basic Books; 1981. 
20. Murphy LJT. History of urology. Springfield: C. Thomas; 1972. p. 20-22

21. Nittis S. The Hippocratic Oath in reference to lithotomy: a new interpretation with historical notes on castration. Bull Hist Med 1939;7:719-28.

22. Edelstein L. The Hippocratic Oath: text, translation and interpretation. In: Temkin 0, Temkin L, editors. Ancient medicine. Baltimore: The Johns Hopkins University Press; 1967. p. 3-65.

23. Kass L. Toward a more natural science: biology and human affairs. New York: Free Press; 1985. p. 235-6.

24. Papavramidou N, Voultsos P. Medical malpractice cases in Hippocratic collection: a review and today's perspective. Hippokratia 2019;23(3):99-105.

25. Hippocrates. Law. In: Page TE, editor. Hippocrates Vol. II. Cambridge: Harvard University Press; 1957. p. 264.

26. Hippocrates. Physician. In: Page TE, editor. Hippocrates Vol. II. Cambridge: Harvard University Press; 1957. p. 312-13.

27. Hippocrates. Decorum. In: Page TE, editor. Hippocrates Vol. II. Cambridge: Harvard University Press; 1957. p. 279-301.
28. Hippocrates. Precepts. In: Page TE, editor. Hippocrates Vol. I. Cambridge: Harvard University Press; 1957. p. 319.

29. Platon. Zakoni. [Laws] Beograd: Dereta, 2004. p. IX 933. Serbian.

30. Radenović S. Bioetika i medicina: odnos ljekar-pacijent u paradigmi integrativne bioetike. [Bioethics and medicine: doctor-patient relationship in the paradigm of integrative bioethics]. Novi Sad: Akademska knjiga; 2012

31. Loewy EH. Oaths for physicians - necessary protection or elaborate hoax? MedGenMed 2007;9(1):7.

32. Veatch RM, Mason CG. Hippocratic vs. judeo-christian medical ethics: principles in conflict. J Relig Ethics 1987;15(1):86105.

33. Hulkwer R. The history of the Hippocratic Oath: outdated, inauthentic, and yet still relevant. Einstein J Biol Med 2010;25(1):41-44.

34. Mountokalakis TD, Modern medical ethics and legacy of Hippocrates. Hosp Chron 2014;9(4):229-31. 